\title{
Порівняльна характеристика перебігу гострих та хронічних ран у хворих на синдром діабетичної стопи на тлі вакуум-терапії
}

\author{
P. O. HERASYMCHUK, V. H. VLASENKO, A. V. PAVLYSHYN \\ SHEI "Ternopil State Medical University by I. Ya. Horbachevsky"
}

\section{COMPARATIVE DESCRIPTION OF ACUTE AND CHRONIC WOUNDS IN PATIENTS WITH DIABETIC FOOT SYNDROME AGAINST THE BACKGROUND OF THE VACUUM THERAPY}

\begin{abstract}
У 45 хворих на синдром діабетичної стопи було проведено порівняльну характеристику перебігу гострих та хронічних ранових процесів на тлі місцевого застосування вакуумної терапії. На основі клінічних, мікробіологічних, цитологічних, планіметричних досліджень та вивчення рівня ендогенної інтоксикації доведено ефективність вакуум-терапії ранових дефектів. Використання даного методу місцевого лікування ран у хворих на синдром діабетичної стопи дозволяє значно покращити результати та скоротити терміни стаціонарного лікування на $(6,2 \pm 1,4)$ дня.

45 patients with diabetic foot syndrome was conducted comparative description of the course of acute and chronic wound processes against the background of the local appliance of vacuum therapy. Based on the clinical, microbiological, cytological, planometric research and scrutiny of endogenous intoxication, the effectiveness of the vacuum therapy of wound defects was proved. Using of the method of topical wound treatment in patients with diabetic foot syndrome allows to significantly improve results and reduce the time of hospital treatment to $(6,2 \pm 1,4)$ days.
\end{abstract}

Постановка проблеми і аналіз останніх досліджень та публікацій.Одниміз основних завдань лікування гнійно-септичних уражень нижніх кінцівок у хворих із синдромом діабетичної стопи (СДС) $\epsilon$ вивчення особливостей перебігу ранового процесу. Це дозволить оптимізувати комплексне лікування вищеозначених хворих. Ранові процеси у вигляді гострих та хронічних ран зустрічаються у 28,665,0 \% хворих на СДС, які на тлі цукрового діабету мають спотворений перебіг [1, 2]. Це зумовлено порушенням периферичної гемодинаміки та трофічних процесів у тканинах нижніх кінцівок, змінами всіх видів обмінних процесів організму, розвитком ацидозу, гіпоксії та метаболічної інтоксикації, наявністю в рані асоціацій анаеробно-аеробної мікрофлори [4-6]. Вказані зміни, поряд з порушеннями біомеханіки стопи, часто призводять до виникнення хронічних ранових дефектів, що потребує відповідних тактичних підходів до лікування [7]. Загоєння ран - складний процес, перебіг якого здійснюється на різних рівнях (молекулярному, субклітинному, клітинному, тканинному, органному) і остаточною метою якого є ліквідація ураження тканин з максимальним відновленням їх анатомічної структури та функціональних можливостей.
Мета роботи: провести порівняльну характеристику особливостей перебігу гострих та хронічних ран у хворих на синдром діабетичної стопи на тлі використання вакуум-терапії.

Матеріали і методи. Обстежено 45 хворих із СДС (основна група) віком від 46 до 68 років. Чоловіків було 27, жінок - 18. Контрольну групу склали 10 хворих на СДС із рановими дефектами, яким у процесі лікування вакуум-терапію не застосовували. Вони були зіставні з основною групою за віком, статтю та характером ураження нижніх кінцівок. Всі хворі були з цукровим діабетом 2 типу. Стадію компенсації діагностовано у 7 пацієнтів, субкомпенсації - у 29 та декомпенсації - у 9 осіб. У групу обстеження ввійшли пацієнти з СДС, ускладненим розвитком гострих гнійно-некротичних ран, які не потребували проведення розширених хірургічних обробок (26 хворих), та хронічних ран (19 хворих). Площа ран коливалася від 1,8 до $8,4 \mathrm{~cm}^{2}$ i в середньому склала $(5,1 \pm 0,9)$ см$^{2}$. Нейропатичноінфіковану форму СДС (НІФ) діагностовано у 24 хворих, а ішемічно-гангренозну (ІГФ) - у 21 пацієнта, розподіл яких проводили залежно від показників гемодинаміки нижніх кінцівок. Аналіз пере- 
бігу ранового процесу виконували комплексно, відповідно до стадій його розвитку. Візуалізацію ран здійснювали, орієнтуючись на такі критерії: ступінь вираження і тривалості запальних змін у ділянці рани (набряк, гіперемія, ексудація), стан дна рани, терміни появи грануляцій, початок та швидкість епітелізації на основі планіметричного методу, з обчисленням індексу Л. Н. Попової (1942). Також вивчали цитологічну картину мазків-відбитків з рани за методом М. П. Покровської та М. С. Макарова (1942) та характер мікрофлори ранових дефектів за загальноприйнятими методиками. Динаміку показників ендогенної інтоксикації вивчали на основі лейкоцитарного індексу інтоксикації (ЛІІ) за Я. Я. Кальф-Каліфом та індексом резистентності організму (IPO), які розраховували на основі розширеного аналізу крові за загальноприйнятими формулами. Дослідження проводили при госпіталізації хворих у стаціонар, на 3-й, 7-й та 14-й день лікування.

Вакуум-терапію ран проводили методом постійного вакуумування за допомогою вітчизняного апарата виробництва фірми “АГАТА-ДНІПРО” зі створенням від'ємного тиску в 125 мм рт. ст. 3 метою накладання вакуумної пов'язки використовували стандартні перев'язувальні набори V.A.C Granu Foam Dressing (USA).

Результати досліджень та їх обговорення. Серед основних факторів ризику, які призводять до виникнення ранових процесів у хворих на СДС, можна виділити такі: порушення біомеханіки стопи, механічну травму, первинні гангренозні процеси. Переважання їх певною мірою залежить від патогенетичної форми СДС. У хворих із НІФ ураження основним фактором, який призводив до розвитку гострих гнійно-некротичних процесів, була механічна травма (66,6 \%), яка викликалася неправильним обрізанням нігтів, вузьким взуттям, прогулянками босоніж, потраплянням сторонніх тіл у взуття, випадковим травмуванням тощо. Тобто, пацієнти нехтували правилами догляду за нижніми кінцівками або були з ними взагалі не обізнані. Клінічна картина проявлялася вираженими озна- ками запалення, набряком тканин, наявністю гнійних виділень, симптомами інтоксикації. Хронічні ранові процеси у цієї групи хворих були переважно пов'язані з порушеннями біомеханіки стопи, які проявлялися у вигляді обмеження рухомості та деформації суглобів, плоскостопості, “молоточкоподібних” пальців, стопи Шарко, за рахунок попередніх хірургічних втручань (33,4 \%). Таким чином, локалізація останніх, як правило, відповідала зонам максимального навантаження. Хронічні рани були поверхневими, неболючими і характеризувалися слабким перифокальним запаленням, дно їх було виповнене в'ялими грануляціями, з помірною ексудацією та вогнищевими некрозами.

У пацієнтів з ІГФ трофічні виразки та хронічні рани виникали внаслідок порушення кровопостачання, розташовувалися переважно в акральних ділянках, міжпальцевих проміжках, в місцях тріщин шкіри, післяопераційних рубців (52,4 \%). Вони супроводжувалися вираженим больовим синдромом. Виразки були зазвичай з некротичним дном, глибокі, пенетрувальні, з вираженим перифокальним запаленням. Гострі гнійно-некротичні ураження у цієї групи пацієнтів виникали як ускладнення первинного ішемічного некрозу тканин або на тлі трофічних виразок та хронічних ран (47,6 \%). Клінічна картина супроводжувалася вираженим больовим синдромом та дещо стертими ознаками гострого запалення, що на тлі порушення кровопостачання утруднювало діагностику поширеності патологічного процесу.

Розвиток гнійно-некротичного процесу переважно у хворих із НІФ ураження викликав появу “феномена взаємного обтяження”, декомпенсацію ЦД та пролонгацію процесу за типом “хибного кола”, що було відмічено у 19,8 \% випадків. Часто патологічний процес не мав тенденції до обмеження, зі швидким поширенням по анатомічних структурах стопи та розвитком септичних ускладнень (11,8 \% випадків). Розвиток гнійної інфекції більш характерний для НІФ (72,4 \%), тоді як у пацієнтів 3 ІГФ переважали гангренозні ураження (73,8 \%).

Вплив вакуум-терапії на клінічний перебіг ранового процесу у хворих на СДС наведено у таблиці 1.

Таблиця 1. Вплив вакуум-терапії на клінічні прояви ран у хворих на Сдс

\begin{tabular}{||c|c|c|c|c|c||}
\hline \multirow{2}{*}{$\begin{array}{c}\text { Групи } \\
\text { хворих }\end{array}$} & $\begin{array}{c}\text { купірування бо- } \\
\text { льового синдрому } \\
\text { (доба) }\end{array}$ & $\begin{array}{c}\text { нормалізація } \\
\text { температури } \\
\text { тіла (доба) }\end{array}$ & $\begin{array}{c}\text { поява активних } \\
\text { грануляцій } \\
\text { (доба) }\end{array}$ & $\begin{array}{c}\text { поява крайової } \\
\text { епітелізації } \\
\text { (доба) }\end{array}$ & $\begin{array}{c}\text { середній } \\
\text { ліжко-день } \\
\text { (доба) }\end{array}$ \\
\hline $\begin{array}{l}\text { Контрольна } \\
\text { група (n=10) }\end{array}$ & $3,52 \pm 0,72$ & $3,67 \pm 0,64$ & $8,74 \pm 0,74$ & $9,82 \pm 1,38$ & $19,61 \pm 2,56$ \\
\hline $\begin{array}{l}\text { Хронічні рани } \\
(\mathrm{n}=19)\end{array}$ & $1,12 \pm 0,48$ & - & $5,86 \pm 1,02$ & $4,36 \pm 0,86$ & $10,42 \pm 1,28$ \\
\hline $\begin{array}{l}\text { Гострі рани } \\
(\mathrm{n}=26)\end{array}$ & $2,36 \pm 0,92$ & $2,13 \pm 0,78$ & $6,96 \pm 1,58$ & $7,52 \pm 1,24$ & $15,47 \pm 1,86$ \\
\hline \hline
\end{tabular}




\section{З ДОСВІДУ РОБОТИ}

Мікробіологічні дослідження дозволили виділити 1140 штамів мікроорганізмів, які у пацієнтів із хронічними ранами віднесені до 6 родин, 10 родів та 37 видів, та з гострими ранами - до 6 родин, 9 родів та 36 видів. У 64,2 \% хворих із гострими гнійнозапальними процесами за характерними клінічними ознаками та забарвленням мазків-відбитків із рани за Грамом діагностовано наявність анаеробної неклостридіальної флори.

Звертає на себе увагу той факт, що у хворих із хронічними ранами колонізація мікроорганізмами ранових дефектів була вищою (4,86 lg КУО/г), ніж у пацієнтів із гострими гнійно-некротичними процесами $(4,12 \lg \mathrm{KУO} / \Gamma)(\mathrm{p}<0,05)$. Це може бути зумовлено порушенням догляду за хронічними ранами з боку хворих та наявністю більшої кількості антибіотикорезистентних штамів. Домінуючі групи мікроорганізмів у рановому вмісті обох видів ран склали стафілококи (5,96-4,83 lg КУО/г), стрептококи (5,42-4,46 lg КУО/г), мікрококи (4,864,21 lg КУО/г), коринебактерії (4,58-4,42 lg КУО/г). У пацієнтів із трофічними виразками, абсцесами, флегмонами з ранових дефектів частіше висівали грампозитивну флору, а у хворих із гнійними ранами, при вологій гангрені - грамнегативну.

У пацієнтів із хронічними ранами на момент госпіталізації цитологічна картина мазка-відбитка з рани відповідала запальному (82,4 \%) або регенераторно-запальному $(17,6$ \%) типу цитограм. Нейтрофільні лейкоцити склали 74,2 \%, 3 наявністю незначної кількості лімфоцитів, моноцитів, макрофагів, полібластів (25,8 \%). Мікрофлора була розташована переважно внутрішньоклітинно в стадії незавершеного фагоцитозу. ЛІІ склав $(3,16 \pm-$

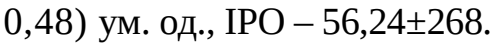

У всіх хворих із гострими ранами відмічено наявність некротичної (74,3 \%) або дегенеративнозапальної (25,7 \%) картини цитограми. У мазкахвідбитках переважали нейтрофільні лейкоцити (92-100 \%), які перебували в стані дегенерації та деструкції. У 86 \% випадків відмічали незавершений або спотворений фагоцитоз. Коково-бацилярна флора розташовувалася поза- та внутрішньоклітинно, фагоцитоз був дегенеративним (81,4 \%) або незавершеним (24,3 \%). Це свідчить про значне зниження клітинної ланки імунітету та відсутність регенеративних процесів, які були більше виражені у хворих 3 гострими ранами. ЛІІ склав $(4,47 \pm 0,62)$ ум. од.,

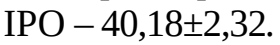

На 3-тю добу у хворих із хронічними ранами мало місце збільшення питомої ваги регенераторнозапального типу цитограм до 32,4 \% та зменшення запальних цитограм до 67,6 \%. Колонізація мікроорганізмами зменшувалася до 4,12 lg КУО/г, хоча зі сторони видового складу мікроорганізмів особливих змін не відбувалося. Мікрофлора була наявна в стані завершеного та незавершеного фагоцитозу (50-60 \%). Кількість нейтрофілів зменшилася до 62,3 \%, зі збільшенням їх цілісності. Лімфоцити, моноцити, макрофаги, полібласти в препаратах зросли до 37,7 \%. ЛІІ склав - $(2,14 \pm 0,26)$ ум. од., IPO - 61,48 $\pm 2,17$.

Позитивна динаміка відмічена і в хворих із гострими ранами. Кількість дегенеративних форм цитограм знизилася до 84,7 \%, натомість з'явились запальні цитограми (15,3%). Колонізація мікроорганізмами зменшилася до $3,98 \mathrm{lg} \mathrm{KУО/г,} \mathrm{зі}$ збільшенням та покращенням фагоцитарної активності нейтрофілів. ЛІІ склав $(3,98 \pm 0,58)$ ум. од., IPO $-46,25 \pm 3,19$.

На 7-му добу вакуум-терапії у хворих із хронічними ранами в 98 \% випадків відмічався регенераторний тип цитограм, з крайовою епітелізацією ран. Кількість мікроорганізмів у рані зменшувалася нижче критичного рівня (1,12 lg КУО/г) зі значним збідненням видового складу мікроорганізмів. ЛІІ становив $(2,14 \pm 0,26)$ ум. од., IPO - 78,18 $\pm 3,92$. Це дозволило провести автодермальне закриття ранових дефектів шляхом автодермопластики у 13 хворих або виписати хворих на амбулаторне лікування (6 пацієнтів) зі залишковими ранами діаметром 0,5-0,8 см.

У 34,6 \% хворих із гострими ранами відмічено наявність регенераторного типу цитограм, у 48,3 \% - запально-регенераторного та у 17,1 \% - запального. Колонізація мікроорганізмами зменшилася до 2,56 lg КУО/г, із зменшенням їх видового розмаїття. Зростала та покращувалася фагоцитарна активність нейтрофілів, яка переважно носила завершений характер. ЛІІ склав $(2,98 \pm 0,62)$ ум. од., IPО

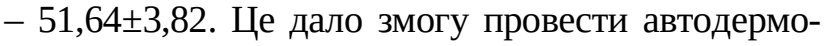
пластику ран 9 пацієнтам.

На 14-ту добу лікування гострих ран відмічалася подальша позитивна динаміка перебігу ранового процесу. Кількість регенераторних типів цитограм зросла до 92,7 \% випадків. ЛІІ склав $(2,28 \pm 0,46)$ ум. од., IPO $-68,72 \pm 3,19$. У ці терміни ранові дефекти були закриті автодермальними клаптями 12 хворим, а 5 пацієнтів виписані на амбулаторне лікування зі залишковими ранами, в яких відмічали виражені процеси крайової епітелізації.

Планіметричні дослідженняпоказали, що індекс Попової на 3-тю добу використання вакуум-терапії у хворих із хронічними ранами склав $(6,2 \pm 08) \%$, у хворих із гострими ранами - $(10,6 \pm 1,4) \%$, контроль - $(2,4 \pm 0,3) \%$. На 7-му добу: хронічні рани $(11,7 \pm 1,9) \%$, гострі рани - $(16,4 \pm 2,4) \%$, контроль $(5,9 \pm 1,1) \%$. На $14-$-у добу у хворих із гострими ранами - $(26,5 \pm 2,6) \%$, контроль - $(13,4 \pm 2,8) \%$. 
Висновки. 1. Використання вакуумної терапії в комплексному лікуванні гострих та хронічних ран у хворих із СДС сприяє скороченню термінів переходу фаз ранового процесу та стимулює репаративні процеси. Це дозволяє перейти до наступного етапу лікування в коротші терміни.

2. Вакуум-терапія в лікуванні СДС дозволяє в коротші терміни закрити рани шляхом автодермопластики, скоротивши стаціонарне лікування на $(6,2 \pm 1,4)$ доби.

3. Позитивний вплив вакуум-терапії на перебіг ранових процесів у хворих на СДС дозволяє рекомендувати ії для широкого використання в клінічній практиці.

\section{СПИСОК ЛІТЕРАТУРИ}

1. Greenhalgh D. G. Wound healing and diabetes mellitus / D. G. Greenhalgh // J. Clin. Plast. Surg. - 2003. - Vol. 30. - № 1. - P. 37-45.

2. Гнойно-некротические осложнения синдрома диабетической стопы и их отражение в МКБ-10 и стандартах страховой медицины / Б. С. Брискин, М. Д. Дибров, Ф. Ф. Хамитов [и др.] // Хирургия. - 2007. - № 1. - С. 49-55.

3. Ефимов А. Синдром диабетической стопы. Эпидемиология, патогенез, клиника, диагностика, лечение трофических поражений нижних конечностей у больных сахарным диабетом / А. Ефимов, С. Болгарская // Ліки України. - 2005. - № 5. - C. 45-53.

4. Тихонова Т. М. Клинико-патогенетические аспекты разви-

тия диабетической стопы / Т. М. Тихонова, С. И. Лысикова // Проблеми ендокринної патології. - 2002. - № 2. - С. 87-93.

5. Коровин А. Я. Хронологическая изменчивость микрофлоры ран и антибактериальная терапия у больных с гнойнонекротическими поражениями нижних конечностей при сахарном диабете / А. Я. Коровин, С. Б. Базлов // Инфекции в хирургии. - 2008. - № 4. - С. 47-50.

6. Удовиченко О. В. Диабетическая стопа / О. В. Удовиченко, Н. М. Грекова. - М. : Практическая медицина, 2010. - 272 с.

7. Токмакова А. Ю. Хронические раны и сахарный диабет: современная концепция и перспективы консервативного лечения / А. Ю. Токмакова, Л. П. Доронина, Г. Ю. Страхова // Сахарный диабет. - 2010. - № 4. - С. 63-67.

Отримано 14.07.15 